\title{
Enhancement of Suckering Behaviour of Anthurium andreanum L. var. Tropical under Naturally Ventilated Polyhouse
}

\author{
N.S. Seemanthini*, S.Y. Chandrashekar, B. Hemla Naik, \\ M. Shivaprasad and M. Ganapathi \\ Department of Floriculture and Landscape Architecture, COH, Mudigere, \\ (UAHS Shivamogga), India \\ *Corresponding author
}

\section{A B S T R A C T}

Keywords

Anthurium, BA, GA3, MH, CCC

Article Info

Accepted:

20 March 2018

Available Online:

10 April 2018
Floriculture has been emerging as a future thrust industry in India and referred as tomorrow's green cultivation. Importance of cut flowers in international flower market makes the growers to take up its cultivation in India. Globally, Anthurium ranks $11^{\text {th }}$ position among the cut flowers and $2^{\text {nd }}$ position among tropical cut flowers. In Karnataka, anthuriums are grown extensively in tropical humid regions viz., Kodagu and Chikkamagaluru districts (Mudigere) for Export purpose. An experiment was conducted during 2016-17 to investigate the effect of growth regulators (BA, GA $3, \mathrm{MH}, \mathrm{CCC}$ ) on suckering habit of Anthurium andreanum var. Tropical under naturally ventilated polyhouse. Results showed that benzyl adenine@750 ppm took least (88.67) days to sucker production. Which is on par with BA @ 500 ppm (90.33), BA @ 250and at the final stage of the experiment (at 240 days after spraying) number of suckers per plant was recorded in highest in BA @ 750 ppm (3.33).

\section{Introduction}

Anthurium andreanum Lind. Commonly called asanthurium is an elegant, glossy surfaced flower. Very much famous among the top ten sold flowers due to its long shelf life and broad leaf spathe and spadix. A perennial evergreen herbaceous, semi terrestrial, epiphytic plant with somewhat creeping habit of growth, using aerial roots for anchorage. Belongs to family Araceae and origin to tropical America (Columbia) with the chromosome of $2 n=30$.It is the national flower of Mauritius. It symbolize 'hospitality' among flowers. Anthuriums are often referred as "tail flower" which is derived from the Greek word 'anthos' means flower and 'oura' means tail referring to the spadix.

The anthurium plant produces flowers throughout the year. Six to eight flowers are obtained per plant per year from the axil of every leaf. The 'true' flowers are found on the spadix and have large numbers of pistils, each surrounded by four stamens. The 'true' flowers are bisexual, protogynous and crosspollinated. Six months after pollination, we can find colored berries on the spadix. Each berry contains one or two seeds that can be planted to generate new plants. Anthurium 
also reproduces vegetatively through suckers, which arise around the base of the stem. The suckers are identical to the mother plant and to each other. Commercial cultivars of anthurium do not produce suckers or produce very few. One such best example is variety Tropical. This variety grabbed prominent position in the international flower market due to its brilliant showy red colour and its long lasting feature, but it has got least sucker production (Latha, 2013).

The highly condensed underground stem often produces multiple shoots at the plant base. Such multiple shoots may be with or without roots can be separated from the mother plant and planted in the main field. Non availability of sufficient planting material of commercially cultivated varieties of anthurium like Tropical at reasonable rates is the major constraints that led to the loss of interest in many growers.

The ability to produce suckers is variety dependent and suckering capacity can be improved by exogenous application of growth regulators at frequent intervals (Srinivasa, 2006). Therefore, the present work is carried out with a view to find the growth regulator for enhancing suckering habit of anthurium

\section{Materials and Methods}

The experiment was carried out during the year 2016 -2017 under naturally ventilated polyhouse situated at College of horticulture,
Mudigere, Department of Floriculture and Landscape architecture, UAHS, Shivamogga. There were 13 treatments including control, with 3 replications.

The trial was laid out in Completely Randomized Block Design and the treatments were foliar application of benzyl adenine (250 ppm, 500 ppm and 750 ppm), Cycocel (1000 ppm, $1500 \mathrm{ppm}$ and $2000 \mathrm{ppm})$, Gibberellic acid (100 ppm, $150 \mathrm{ppm}$ and $200 \mathrm{ppm})$ and Maleic hydrazide (100 ppm, 150 ppm and 200 $\mathrm{ppm}$ ) at three months after planting. Days to sucker production and number of suckers/plant recorded at monthly intervals.

\section{Results and Discussion}

The data pertaining to the days to suckers production differed significantly among treated plants at all stages of plant growth were presented in Table 1.

During the experimental period, $\mathrm{T}_{3}-\mathrm{BA}$ @ 750 ppm took least (88.67) days to sucker production. Which is on par with $\mathrm{T}_{2}-\mathrm{BA}$ @ 500 ppm (90.33), T1-BA @ 250 ppm (101.00), $\mathrm{T}_{9}-\mathrm{GA}_{3} @ 200 \mathrm{ppm}$ (105.00), $\mathrm{T}_{6}-\mathrm{CCC} @$ 2000 ppm (124.33) and $\mathrm{T}_{5}$-CCC @ 1500 ppm (135.33) Throughout the experimental period, T $4-\mathrm{CCC} @ 1000$ ppm, T $6-\mathrm{GA}_{3} @ 100$ ppm, $\mathrm{T}_{7}-\mathrm{GA}_{3} @ 150$ ppm, T $10-\mathrm{MH} @ 100$ ppm, $\mathrm{T}_{11}-\mathrm{MH} @ 150 \mathrm{ppm}, \mathrm{T}_{12}-\mathrm{MH} @ 200$ ppm and $\mathrm{T}_{13}-$ control showed no response for days to sucker production.

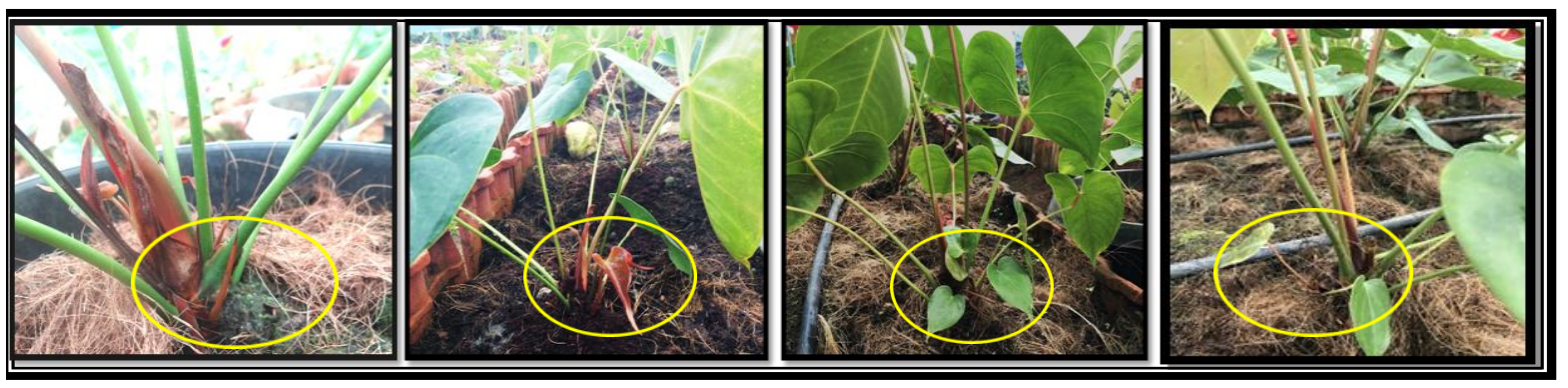

Plate 1. Suckering of anthurium as influenced by growth regulators at different stages of crop growth 
Table.1 Days to sucker production and suckers produce per plant of Anthurium andreanum var. Tropical as influenced by growth regulators under protected condition

\begin{tabular}{|c|c|c|c|c|c|c|c|c|c|c|}
\hline \multirow{2}{*}{\multicolumn{2}{|c|}{ Treatment }} & \multirow{3}{*}{$\begin{array}{l}\text { Days to } \\
\text { sucker } \\
\text { production }\end{array}$} & \multicolumn{8}{|c|}{ Number of suckers/plant } \\
\hline & & & \multicolumn{8}{|c|}{ Days after spray } \\
\hline No. & Details & & 30 & 60 & 90 & 120 & 150 & 180 & 210 & 240 \\
\hline$\overline{T_{1}}$ & BA@ 250ppm & 101.00 & 0.00 & 0.00 & 0.00 & 0.33 & 0.46 & 0.66 & 1.00 & 1.60 \\
\hline$T_{2}$ & BA@ 500ppm & 90.33 & 0.00 & 0.00 & 0.53 & 0.73 & 0.93 & 1.13 & 1.90 & 2.10 \\
\hline $\mathrm{T}_{3}$ & BA@750ppm & 88.67 & 0.00 & 0.00 & 0.80 & 1.13 & 1.46 & 1.8 & 2.40 & 3.33 \\
\hline $\mathbf{T}_{4}$ & CCC@1000ppm & 0.00 & 0.00 & 0.00 & 0.00 & 0.00 & 0.00 & 0.00 & 0.00 & 0.00 \\
\hline$T_{5}$ & CCC@1500ppm & 135.33 & 0.00 & 0.00 & 0.00 & 0.00 & 0.00 & 0.00 & 0.77 & 0.93 \\
\hline$T_{6}$ & CCC@2000ppm & 124.33 & 0.00 & 0.00 & 0.00 & 0.26 & 0.46 & 0.66 & 1.00 & 1.23 \\
\hline $\mathbf{T}_{7}$ & GA $3 @ 100 p p m$ & 0.00 & 0.00 & 0.00 & 0.00 & 0.00 & 0.00 & 0.00 & 0.00 & 0.00 \\
\hline $\mathrm{T}_{8}$ & GA $3 @ 150 p p m$ & 0.00 & 0.00 & 0.00 & 0.00 & 0.00 & 0.00 & 0.00 & 0.00 & 0.00 \\
\hline$T_{9}$ & GA $3 @$ @200ppm & 105.67 & 0.00 & 0.00 & 0.00 & 0.40 & 0.53 & 0.80 & 1.07 & 1.30 \\
\hline$T_{10}$ & MH @ 100ppm & 0.00 & 0.00 & 0.00 & 0.00 & 0.00 & 0.00 & 0.00 & 0.00 & 0.00 \\
\hline$T_{11}$ & MH@150ppm & 0.00 & 0.00 & 0.00 & 0.00 & 0.00 & 0.00 & 0.00 & 0.00 & 0.00 \\
\hline$T_{12}$ & MH@ 200ppm & 0.00 & 0.00 & 0.00 & 0.00 & 0.00 & 0.00 & 0.00 & 0.00 & 0.00 \\
\hline 1 & Control & 0.00 & 0.00 & 0.00 & 0.00 & 0.00 & 0.00 & 0.00 & 0.00 & 0.00 \\
\hline & S. Em \pm & 18.85 & 0.00 & 0.00 & 0.04 & 0.04 & 0.04 & 0.04 & 0.14 & 0.19 \\
\hline & CD @ $5^{c}$ & 55.01 & 0.00 & 0.00 & 0.11 & 0.10 & 0.12 & 0.12 & 0.41 & 0.55 \\
\hline
\end{tabular}

The data pertaining to the number of suckers produced per plant which differed significantly among the different growth regulators treated plants at different stages of crop growth are presented in Table 1.

The number of suckers produced per plant during the experimental period was significantly influenced by different level of growth regulators. During the experimental period, $\mathrm{T}_{3}-\mathrm{BA} @ 750 \mathrm{ppm}$ treated plants produced maximum number of suckers per plant as compared to all other treatments.

At the final stage of the experiment (at 240 days after spraying) number of suckers per plant was recorded in $\mathrm{T}_{3}-\mathrm{BA}$ @ 750 ppm (3.33).Till 240 days after spraying there was no record of sucker production per plant was observed in $\mathrm{T}_{4}-\mathrm{CCC} @ 1000$ ppm, $\mathrm{T}_{7}-\mathrm{GA}_{3}$ @ 100 ppm, $\mathrm{T}_{8}-\mathrm{GA}_{3} @ 150$ ppm, $\mathrm{T}_{10}-\mathrm{MH} @$ 100 ppm, $\mathrm{T}_{11}-\mathrm{MH} @ 150$ ppm, $\mathrm{T}_{12}-\mathrm{MH} @$ $200 \mathrm{ppm}$ and $\mathrm{T}_{13}-$ control.
Significant influence of different growth regulators on number of days taken to sucker production and number of suckers produced per plant (Table 1) was recorded at monthly intervals. Throughout the experimental period BA @ 750 ppm exhibited minimum days to sucker production and maximum number of suckers per plant. It has been studied that number of suckers per plant increases parallel with the increase in the growth stage of the plant. And 240 days after spray it found maximum in plant treated with BA @ 750 ppm.

It might be the effect of cytokinins on increasing in the rate of cell division and to induce bud break in above ground and underground plant parts. As reported by Srinivasa (2006) this can be due to release apical dominance caused by greater quantity of cytokinin (BA) applied leading to the auxin: cytokinin ratio. The auxin synthesis inhibiting effect of BA that indirectly helps to 
produce laterals which are further reported by Salvi (1997), Chandrappa (2002) and Maitra and Roychowdhury (2014) in anthurium.

\section{References}

Chandrappa, 2002, Evaluation and effect of media, bio fertilizers and growth regulators on growth and flowering in anthuriums. Ph.D. thesis, Univ. Agric. Sci., Bangalore, Karnataka, p.146.

Latha, S., 2013, Evaluation of anthurium cultivars for their performance under protected cultivation. M. Sc. thesis, Univ. Hort. Sci., Bagalkot, Karnataka (India).p.119.

Maitra, S., and Roychowdhury, N., 2014, Effect of gibberellin and cytokinin on sucker production and flowering of anthurium (Anthurium andreanum Lind.)cv. Nitta in the plains of West Bengal. Int. J. Bioinformatics Biol. Sci., 2(1):41-53.

Salvi, B. R., 1997, Optimization of shade, nutrients and growth regulators for cut flower production in anthurium. Ph.D. thesis, Univ. Agric. Sci., Thrissur, Kerala (India). p.167.

Srinivasa, V., 2006, BA induced productionin Anthurium andreanum cv Senator. Environ. Ecol.., 24(4): 1034-1036.

Srinivasa, V., 2006, Influence of BA on sucker production in Anthurium andreanum cv. Hondura. Res. Crops., 7(1): $285-287$

\section{How to cite this article:}

Seemanthini, N.S., S.Y. Chandrashekar, B. Hemla Naik, M. Shivaprasad and Ganapathi, M. 2018. Enhancement of Suckering Behaviour of Anthurium andreanum L. var. Tropical under Naturally Ventilated Polyhouse. Int.J.Curr.Microbiol.App.Sci. 7(04): 2252-2255. doi: https://doi.org/10.20546/ijcmas.2018.704.257 